\title{
Waterlogging tolerance of grass pea (Lathyrus sativus L.) at germination related to country of origin
}

\author{
Edi Wiraguna $^{1, *}\left(\mathbb{D}\right.$, Al Imran Malik ${ }^{1,2}(\mathbb{D})$, Timothy David Colmer ${ }^{1,3}$ (D) and William Erskine ${ }^{1,2,3}$ (D) \\ ${ }^{1}$ UWA School of Agriculture and Environment, The University of Western Australia, 35 Stirling Highway, Crawley, WA 6009, \\ Australia, ${ }^{2}$ Centre for Plant Genetics and Breeding, The University of Western Australia, 35 Stirling Highway, Crawley, WA \\ 6009, Australia and ${ }^{3}$ Institute of Agriculture, The University of Western Australia, 35 Stirling Highway, Crawley, WA 6009, \\ Australia \\ *Corresponding author. Email: edi.wiraguna@research.uwa.edu.au
}

(Received 6 May 2020; revised 27 August 2020; accepted 2 November 2020; first published online 10 December 2020)

\begin{abstract}
Grass pea (Lathyrus sativus L.) has a Mediterranean origin and was spread to Western Europe, Africa and South Asia. Over time, this grain legume crop has become important in South Asia, where it is often affected by waterlogging at germination. Therefore, varieties with waterlogging tolerance of seeds at germination are needed. This study evaluated waterlogging tolerance in a grass pea diversity panel. First, morphoagronomic traits of 53 grass pea genotypes from 7 diverse countries (Afghanistan, Australia, Bangladesh, Cyprus, Ethiopia, Greece and Pakistan) were measured in a glasshouse. Seeds of the collection were then sown into waterlogged soil for 6 days and is subsequently drained for 8 days. Finally, representative genotypes from each country of origin of the three survival patterns (described below) were then tested to identify the effect of seed priming on germination and seedling growth in waterlogged soil. Canonical analysis of six traits (seed weight, pod length, pod width, flowering time, time to maturity and seedling survival) showed that genotypes from Bangladesh and Ethiopia were similar. There was a significant variation amongst genotypes in waterlogging tolerance. Genotypes from Bangladesh and Ethiopia showed the highest percent seedling survival (54\% and $47 \%$ ), with an ability to germinate under waterlogging and then maintain growth from the first day of draining to the final sampling (Pattern 1). In contrast, genotypes from other origins either germinated during waterlogging, but did not survive during drainage (Pattern 2) or failed to germinate and had low seedling survival during waterlogging and drainage (Pattern 3). Priming seeds reduced seedling survival in grass pea. Despite Mediterranean origin, specific ecotypes of grass pea with greater waterlogging tolerance under warm wet conditions have been favoured in Bangladesh and Ethiopia where adaptation to extreme precipitation events at germination and seedling survival upon soil drainage is critical for successful crops.
\end{abstract}

Keywords: Soil flooding; Lathyrus sativus; Genotypic diversity; Origins; Legume crop; Shading; Seed priming

\section{Introduction}

Grass pea (Lathyrus sativus L.) originates from the Near East (Mediterranean) where it is grown as a winter crop (Campbell, 1997; Kislev, 1989). The crop was taken to Western Europe, South Asia, e.g. Bangladesh, and Africa, e.g. Ethiopia, where it grows from arid or semi-arid conditions through to waterlogged soil (Campbell, 1997). It is now an important grain legume crop in Bangladesh, Ethiopia and Pakistan (Benková and Zakova, 2001; Campbell et al., 1994; Tadesse and Bekele, 2001; Yigzaw et al., 2001).

Current address: Al Imran Malik, International Centre for Tropical Agriculture (CIAT-Asia), Lao PDR Office, Ban Nongviengkham, Dong Dok, Vientiane, Lao PDR

(c) The Author(s), 2020. Published by Cambridge University Press. This is an Open Access article, distributed under the terms of the Creative Commons Attribution licence (http://creativecommons.org/licenses/by/4.0/), which permits unrestricted re-use, distribution, and reproduction in any medium, provided the original work is properly cited. 
Grass pea is valued because of the high protein content ( 27\%) of its seeds, higher than chickpea (Cicer arietinum L., $~ 18 \%$ ) and similar to that of field pea (Pisum sativum L.) and faba bean (Vicia faba L.), serving as a source of protein for the large population in South Asia (Yan et al., 2006). Consumption of grass pea as a primary dietary component for more than 3 months, however, may cause neurolathyrism due to the presence of $\beta$-N-oxalyl-L-a,b-diaminopropionic acid ( $\beta$-ODAP) in the seeds (Campbell, 1997; Yan et al., 2006). Consumption of grass pea has no negative effects when it is a minor component of the diet ( $<20 \%$ of total protein consumption) (Yan et al., 2006).

Grass pea is reputed to be tolerant to abiotic stresses, e.g. drought, flooding and low soil fertility (Benková and Zakova, 2001; Campbell et al., 1994; Tadesse and Bekele, 2001; Yigzaw et al., 2001). Grass pea crops are often exposed to waterlogging at germination in South Asia as farmers broadcast seeds on to soil under near-mature rice crops, a practice called 'relay cropping' (Campbell et al., 1994; Gupta and Bhowmick, 2005) - often the soil is saturated from unseasonal rains (Campbell, 1997). In Africa, particularly in Ethiopia, grass pea is grown during the monsoon season, i.e. August or September, in soils with a high clay content, which is prone to water ponding and/or waterlogging (Minta et al., 2014; Tadesse and Bekele, 2001) and it is then subjected to drought during maturity (Campbell, 1997).

Waterlogging causes a decrease and/or failure of germination, as a result of oxygen shortage experienced by seeds (Orchard and So, 1985; Zaman et al., 2018). Exposure to an extended period of waterlogging, i.e. lack of oxygen, causes membrane deterioration and the leakage of cellular contents resulting in germination failure and/or seed death (Johnson et al., 1989; Zaman et al., 2019a). However, seeds of some species can tolerate waterlogging and germinate under water (escape mechanism) or survive and germinate after the water recedes (quiescence mechanism) (Hsu and Tung, 2017; Zaman et al., 2019a). For example, rice (Oryza sativa L.) seeds can germinate and elongate the coleoptile, which can function as a 'snorkel' at the water surface, so oxygen is then supplied to the seedling (Hsu and Tung, 2017; Ismail et al., 2009). The second example is field pea seeds with reddish-brown testa colour, which remain quiescent during waterlogging and then germinate upon draining when oxygen is again available (Zaman et al., 2019a).

Seed priming of grain legumes, e.g. lentil and grass pea, can increase seedling establishment and grain yield in relay cropping systems (Ali et al., 2009; Bhowmick et al., 2014). Increased activities of amylase and alcohol dehydrogenase during seed priming are probably the reason for an increase of germination percentage and seedling establishment under relay cropping for primed in comparison with non-primed seeds (Choudhary et al., 2019; Sarkar, 2012). Seed priming leads to faster seedling emergence, earlier flowering and maturity than non-priming in chickpea (Harris et al., 1999). In lentil (Lens culinaris Medik. subsp. culinaris) (Ali et al., 2009; Bhowmick, 2010) and grass pea (Bhowmick et al., 2014), seed priming increased grain yields by $14-17 \%$ and $8 \%$, respectively, compared to crops established from non-primed seed under relay cropping. However, there is no information on the interaction of seed priming on survival under waterlogging during germination in grass pea.

Tolerance to waterlogging at germination and emergence has been correlated with morphoagronomic traits in grain legumes (Sayama et al., 2009; Wiraguna et al., 2017; Zaman et al., 2018). In lentil, for example, early maturity was correlated $(r=0.64)$ with waterlogging tolerance at germination when seeds were waterlogged for 6 days in a pot soil experiment (Wiraguna et al., 2017). When seeds of the soybean (Glycine $\max$ (L.) Merr.) were soaked in distilled water for 48 hours, small seeds showed higher germination and seedling survival than large seeds with a correlation ( $r$ ) of -0.62 between germination and seed weight, and of -0.57 between seedling survival and seed weight (Sayama et al., 2009). Waterlogging tolerance in small seeds of soybean was associated with high levels of proline-rich proteins in the cell wall of the seed coat which slow water imbibition in small seeds more than in large seeds (Percy et al., 1999; Sayama et al., 2009). However, correlations of morpho-agronomic traits of grass pea with waterlogging tolerance at germination have not been reported. 
Given the informal reputation of grass pea, amongst grain legumes, as being waterlogging tolerant, this study was designed to investigate three questions: (1) Does variation in waterlogging tolerance exist in grass pea and does this relate to the genotypic country of origin?; (2) Is waterlogging tolerance correlated with morpho-agronomic traits?; and (3) How does seed priming affect the tolerance of grass pea to waterlogging?.

\section{Materials and Methods}

The study comprised of three components: Experiment 1 - Morpho-agronomic variation in a diversity panel of grass pea genotypes (Table 1); Experiment 2 - Diversity in waterlogging tolerance at germination in the same panel; and Experiment 3 - Evaluation of the effect of seed priming on waterlogging tolerance on a subsample of the diversity panel.

The experiments were conducted in a glasshouse at the University of Western Australia (UWA), Crawley, Western Australia (31 ${ }^{\circ} 59^{\prime} \mathrm{S}$ and $\left.115^{\circ} 49^{\prime} \mathrm{E}\right)$. Experiment 1 was conducted from September 2016 to January 2017 when photosynthetically active radiation (PAR) was $897 \pm 3 \mu \mathrm{mol} \mathrm{m} \mathrm{m}^{-2} \mathrm{~s}^{-1}$ at midday, i.e. 12:00-1:00 pm. Experiments 2 and 3 were conducted between July and August 2018, when the average temperature was $27.7 \pm 0.05^{\circ} \mathrm{C}$ in the day and $24.2 \pm 0.03$ ${ }^{\circ} \mathrm{C}$ at night with the range of $20-32{ }^{\circ} \mathrm{C}$. Relative humidity $(\mathrm{RH})$ was $44.6 \pm 0.18 \%$ in the day and $50 \pm 0.12 \%$ at night with the range of $23-66 \%$ during Experiments 2 and 3. Shade cloth was used in Experiments 2 and 3 with plants receiving $59 \pm 4 \mu \mathrm{mol} \mathrm{m}^{-2} \mathrm{~s}^{-1}$ of PAR at midday to simulate the low light environment under a dense rice crop canopy as encountered in relay cropping.

\section{Experiment 1 - Morpho-agronomic traits of a diversity panel of 53 genotypes}

A diversity panel of 53 genotypes of grass pea from 7 countries with the number of genotypes in parentheses: Afghanistan (9), Australia (3), Bangladesh (3), Cyprus (11), Ethiopia (10), Greece (8) and Pakistan (9) (obtained from the Australian Grains Genebank, Horsham, Victoria) (Table 1) was grown to maturity in a glasshouse in a completely randomised design with three replicates for morpho-agronomic characterisation. The experimental unit was a single pot, diameter $260 \mathrm{~mm}$ and height $230 \mathrm{~mm}$. Six seeds were sown in each pot and after 21 days, seedlings were thinned to four plants per pot. Each pot contained $\sim 4.1 \mathrm{~kg}$ of potting mix (5:2:3 of pine bark: coco peat: brown river sand). Twenty-eight days after sowing (DAS), $1 \mathrm{~g}$ of compound fertiliser (7.3\% nitrogen, $11 \%$ phosphorus, $28 \%$ potassium, $2.8 \%$ sulphur, $0.21 \%$ iron, $0.1 \%$ manganese, $0.08 \%$ boron, $0.06 \%$ zinc, $0.008 \%$ molybdenum) was added to each pot. Forty-nine DAS, this fertiliser was applied twice weekly and the fertiliser application was terminated when $25 \%$ of plants formed pods as described by Wiraguna et al. (2017). Watering was terminated when pods were swollen and filled. Plants were harvested when $90 \%$ of pods turned a grey colour and leaves turned into yellow at growth stage R8 (Campbell, 1997; Erskine et al., 1990).

\section{Experiment 2 - Screening a diversity panel of 53 genotypes for waterlogging tolerance at germination and seedling establishment}

Experiment 2 comprised of two factors: duration of waterlogging and grass pea genotypes in a randomised complete block design (RCBD) replicated 3 times. The first factor - duration of waterlogging - had two levels: 0 (control) and 6 days of waterlogging followed by 8 days of drainage because our preliminary experiment showed that 6 days of waterlogging gave maximum differentiation in waterlogging tolerance amongst grass pea genotypes (data not shown). The second factor comprised of grass pea germplasm with 53 genotypes (Table 1). Seeds were surface sterilised with $1 \%$ commercial bleach (active ingredients $\mathrm{NaOCl} 40 \mathrm{mg} \mathrm{L}^{-1}$ ) for 1 minute and washed in deionised (DI) water 3 times ( 30 seconds in each wash), and fungicide (Tetramethylthiuram disulphide) at the rate of $3 \mathrm{~g} \mathrm{~kg}^{-1}$ seeds were applied before sowing (Zaman et al., 2018). 
Table 1. Grass pea genotypes in the diversity panel of Experiments 1 and 2, and the subset used in Experiment 3 (Exp. 3), with the country of origin, seed viability (\%), germination (\%), seedling survival (\%) and classified for the pattern of seedling survival when sown into waterlogged soil which was subsequently drained. Pattern of seedling survival was assigned based on percent seedling survival between 4 and 14 DAS and cluster analysis (explained below)

\begin{tabular}{|c|c|c|c|c|c|c|c|}
\hline No. & Name & $\begin{array}{l}\text { Country } \\
\text { of origin }\end{array}$ & Exp. 3 & Seed viability (\%) & Germination (\%) & $\begin{array}{c}\text { Seedling } \\
\text { survival (\%) }\end{array}$ & $\begin{array}{c}\text { Pattern of } \\
\text { seedling } \\
\text { survival }\end{array}$ \\
\hline 1 & CPI 24772 & Afghanistan & & $97 \pm 3.3$ & $18 \pm 9.7$ & $0 \pm 0$ & 2 \\
\hline 2 & IFLA 235 & Afghanistan & & $93 \pm 3.8$ & $31 \pm 9.7$ & $2.2 \pm 2.2$ & 2 \\
\hline 3 & IFLA 239 & Afghanistan & $x$ & $87 \pm 8.8$ & $62 \pm 10$ & $4.8 \pm 4.8$ & 2 \\
\hline 4 & IFLA 240 & Afghanistan & & $80 \pm 7.7$ & $46 \pm 17$ & $5.1 \pm 2.6$ & 2 \\
\hline 5 & IFLA 241 & Afghanistan & & $60 \pm 7.7$ & $52 \pm 3.0$ & $3.0 \pm 3.0$ & 2 \\
\hline 6 & IFLA 244 & Afghanistan & $x$ & $63 \pm 6.7$ & $6.7 \pm 3.3$ & $23 \pm 14$ & 3 \\
\hline 7 & IFLA 246 & Afghanistan & & $70 \pm 5.8$ & $41 \pm 20$ & $2.6 \pm 2.6$ & 2 \\
\hline 8 & IFLA 248 & Afghanistan & $\mathrm{x}$ & $80 \pm 11.5$ & $52 \pm 4.8$ & $0 \pm 0$ & 2 \\
\hline 9 & IFLA 251 & Afghanistan & $x$ & $93 \pm 6.7$ & $59 \pm 2.6$ & $0 \pm 0$ & 2 \\
\hline 10 & Ceora & Australia & $x$ & $60 \pm 5.8$ & $49 \pm 5.1$ & $0 \pm 0$ & 2 \\
\hline 11 & Chalus & Australia & $x$ & $100 \pm 0$ & $36 \pm 8.0$ & $8.9 \pm 8.9$ & 2 \\
\hline 12 & IFLA 21 & Australia & & $83 \pm 6.7$ & $5.1 \pm 5.1$ & $0 \pm 0$ & 3 \\
\hline 13 & 8603 & Bangladesh & $x$ & $70 \pm 10$ & $40 \pm 5.8$ & $43 \pm 8.8$ & 1 \\
\hline 14 & 8604 & Bangladesh & $x$ & $73 \pm 8.8$ & $71 \pm 8.0$ & $47 \pm 6.7$ & 1 \\
\hline 15 & 8605 & Bangladesh & $x$ & $47 \pm 7.7$ & $67 \pm 33$ & $89 \pm 11$ & 1 \\
\hline 16 & CPI 10782 & Cyprus & & $73 \pm 14.5$ & $31 \pm 19$ & $8.9 \pm 5.9$ & 2 \\
\hline 17 & CPI 16230 & Cyprus & $x$ & $67 \pm 13.3$ & $10 \pm 6.8$ & $0 \pm 0$ & 3 \\
\hline 18 & CPI 20487 & Cyprus & $x$ & $83 \pm 8.8$ & $17 \pm 6.3$ & $41 \pm 6.3$ & 1 \\
\hline 19 & CPI 20490 & Cyprus & $x$ & $93 \pm 3.3$ & $11 \pm 11$ & $0 \pm 0$ & 2 \\
\hline 20 & CPI 20491 & Cyprus & & $93 \pm 3.3$ & $12 \pm 5.6$ & $2.8 \pm 2.8$ & 3 \\
\hline 21 & CPI 20492 & Cyprus & $x$ & $73 \pm 8.8$ & $15 \pm 8.0$ & $6.1 \pm 3.0$ & 3 \\
\hline 22 & CPI 20495 & Cyprus & $x$ & $90 \pm 5.8$ & $6.7 \pm 3.8$ & $13 \pm 10.2$ & 3 \\
\hline 23 & CPI 9997 & Cyprus & $x$ & $97 \pm 3.3$ & $18 \pm 5.9$ & $8.9 \pm 8.9$ & 3 \\
\hline 24 & IFLA 320 & Cyprus & & $37 \pm 8.8$ & $0 \pm 0$ & $17 \pm 8.3$ & 3 \\
\hline 25 & SEL 471 & Cyprus & & $93 \pm 3.3$ & $26 \pm 5.1$ & $5.1 \pm 2.6$ & 3 \\
\hline 26 & SEL 534 & Cyprus & & $87 \pm 3.3$ & $5.6 \pm 5.6$ & $11 \pm 11$ & 3 \\
\hline 27 & GP.13 & Ethiopia & $x$ & $90 \pm 5.8$ & $88 \pm 4.8$ & $83 \pm 4.8$ & 1 \\
\hline 28 & GP.14 & Ethiopia & & $93 \pm 3.3$ & $76 \pm 6.3$ & $45 \pm 22$ & 1 \\
\hline 29 & GP.15 & Ethiopia & & $43 \pm 3.3$ & $76 \pm 13$ & $15 \pm 8.0$ & 1 \\
\hline 30 & GP.16 & Ethiopia & $x$ & $60 \pm 10$ & $49 \pm 13$ & $58 \pm 17$ & 1 \\
\hline 31 & GP.2 & Ethiopia & & $93 \pm 3.3$ & $61 \pm 6.1$ & $42 \pm 11$ & 1 \\
\hline 32 & GP.27 & Ethiopia & & $90 \pm 5.8$ & $75 \pm 12$ & $53 \pm 7.3$ & 1 \\
\hline 33 & GP.29 & Ethiopia & $x$ & $80 \pm 10.2$ & $44 \pm 5.1$ & $56 \pm 24$ & 1 \\
\hline 34 & GP.30 & Ethiopia & & $73 \pm 17.6$ & $62 \pm 16$ & $31 \pm 6.3$ & 1 \\
\hline 35 & SEL 508 & Ethiopia & & $93 \pm 6.7$ & $52 \pm 8.6$ & $19 \pm 16$ & 2 \\
\hline 36 & SEL 526 & Ethiopia & & $60 \pm 15.3$ & $33 \pm 9.6$ & $36 \pm 15$ & 1 \\
\hline 37 & CPI 14162 & Greece & $x$ & $77 \pm 8.8$ & $0 \pm 0$ & $39 \pm 2.8$ & 1 \\
\hline 38 & CPI 14162.1 & Greece & $x$ & $73 \pm 8.8$ & $23 \pm 11$ & $5.1 \pm 5.1$ & 3 \\
\hline 39 & CPI 14162.3 & Greece & $x$ & $70 \pm 5.8$ & $0 \pm 0$ & $2.8 \pm 2.8$ & 3 \\
\hline 40 & CPI 31617 & Greece & & $80 \pm 5.8$ & $23 \pm 23$ & $3.3 \pm 3.3$ & 3 \\
\hline 41 & IFLA 247 & Greece & & $77 \pm 8.8$ & $83 \pm 6.3$ & $0 \pm 0$ & 2 \\
\hline 42 & SEL 38 & Greece & $x$ & $90 \pm 5.8$ & $5.1 \pm 5.1$ & $10 \pm 6.8$ & 3 \\
\hline 43 & SEL 439 & Greece & & $60 \pm 6.7$ & $11 \pm \pm 11$ & $7.4 \pm 3.7$ & 3 \\
\hline 44 & Site 41.4 & Greece & $x$ & $57 \pm 8.8$ & $0 \pm 0$ & $42 \pm 30$ & 3 \\
\hline 45 & $\mathrm{~K} 100.23$ & Pakistan & $x$ & $87 \pm 8.8$ & $74 \pm 4.8$ & $0 \pm 0$ & 2 \\
\hline 46 & K100.24 & Pakistan & & $90 \pm 5.8$ & $100 \pm 0$ & $0 \pm 0$ & 2 \\
\hline 47 & $\mathrm{~K} 100.31$ & Pakistan & & $100 \pm 0$ & $95 \pm 4.8$ & $0 \pm 0$ & 2 \\
\hline 48 & K100.32 & Pakistan & & $100 \pm 0$ & $92 \pm 8.3$ & $8.3 \pm 8.3$ & 2 \\
\hline 49 & K100.33 & Pakistan & & $100 \pm 0$ & $51 \pm 2.2$ & $2.2 \pm 2.2$ & 2 \\
\hline 50 & K100.35 & Pakistan & & $100 \pm 0$ & $59 \pm 6.8$ & $5.1 \pm 5.1$ & 2 \\
\hline 51 & K100.36 & Pakistan & & $100 \pm 0$ & $58 \pm 12$ & $0 \pm 0$ & 2 \\
\hline
\end{tabular}


Table 1. (Continued)

\begin{tabular}{|c|c|c|c|c|c|c|c|}
\hline No. & Name & $\begin{array}{l}\text { Country } \\
\text { of origin }\end{array}$ & Exp. 3 & Seed viability (\%) & Germination (\%) & $\begin{array}{c}\text { Seedling } \\
\text { survival (\%) }\end{array}$ & $\begin{array}{c}\text { Pattern of } \\
\text { seedling } \\
\text { survival }\end{array}$ \\
\hline 52 & $\mathrm{~K} 100.8$ & Pakistan & $x$ & $100 \pm 0$ & $62 \pm 2.4$ & $4.8 \pm 4.8$ & 2 \\
\hline \multirow[t]{4}{*}{53} & K209.12 & Pakistan & $\mathrm{x}$ & $100 \pm 0$ & $81 \pm 12$ & $0 \pm 0$ & 2 \\
\hline & Mean & & & 80.1 & 41.9 & 17.4 & \\
\hline & F probability $(p)$ & & & $<0.001$ & $<0.001$ & $<0.001$ & \\
\hline & LSD & & & 21.6 & 28.9 & 25.4 & \\
\hline
\end{tabular}

Differences between genotypes were significant for percent seed viability, germination and seedling survival with the least significant differences (LSD) at $p=0.05$. Seed viability of each genotype was tested in Petri dishes for 6 days in a temperature-controlled room ( $25^{\circ}$ C). Germination (\%) under waterlogging \pm standard error from three replicates were derived after dividing treatment data by a number of germinated seeds of the drained control in Experiment 2. Seedling survival (\%) at harvest \pm standard error from three replicates was derived after dividing treatment data by the final number of surviving seedlings of the drained control in Experiment 2. Pattern 1 of seedling survival: Genotypes germinated under waterlogging and survived during subsequent drainage. Pattern 2: Genotypes germinated under waterlogging but failed to survive during subsequent drainage. Pattern 3: Genotypes failed to germinate or had low seedling survival under waterlogging and subsequent drainage.

The diversity panel of 53 genotypes of grass pea was screened for waterlogging tolerance in a pot experiment in free-draining black plastic pots $(85 \times 85 \times 180 \mathrm{~mm})$. Each pot contained $\sim 0.8 \mathrm{~kg}$ soil from Mukinbudin, Western Australia with particle size less than $2 \mathrm{~mm}, \mathrm{pH} 8.2$ and EC $589 \mu \mathrm{s} \mathrm{cm}^{-1}$ (both in 1:5 soil:water). This substrate has been previously used for waterlogging research on field pea by Zaman et al. $(2018 ; 2019 \mathrm{a})$. A total of $0.76 \mathrm{~g}$ compound fertiliser (7.3\% nitrogen, $11 \%$ phosphorus, $28 \%$ potassium, $2.8 \%$ sulphur, $0.21 \%$ iron, $0.1 \%$ manganese, $0.08 \%$ boron, $0.06 \%$ zinc, $0.008 \%$ molybdenum) was applied to the soil in each pot (dissolved and watered when wetting up the soil). Treatment pots were waterlogged for 4 days prior to sowing. Control pots were waterlogged (with DI water) for 3 days and then drained for 1 day to reach field capacity ( $20.8 \%$ water content in soil) prior to sowing.

Fifteen seeds per genotype were placed in each plastic pot, and all pots were placed into a series of plastic tanks, with 18 plastic pots within each $60 \mathrm{~L}$ plastic tank. Each pot had been watered, and then $50 \%$ of the tanks had DI water added into the tank and the DI water entered the bottom of the pots and rose to above the soil surface in pots in those treatment tanks. The seeds were pressed into the soil, e.g. dibbled, with one side of each seed exposed at the surface, i.e. mimicking relay sowing and allowing sufficient moisture in the drained control pots for seeds to germinate. This dibbled practice also helped to identify seed germination because the radicle could be observed on emergence. Controls (drained pots in tanks without water added to the tanks) were sprayed with DI water 4-5 times a day in the first week and 2-3 times a day in the second week after sowing to maintain surface soil moisture. For the treatment of 6 days of waterlogging, the water level was checked daily and maintained at $\sim 9 \mathrm{~mm}$ above the soil level. Water was then sprayed 2-3 times a day during drainage of pots in the previously waterlogged treatment. The seedlings were harvested at 14 DAS.

Low soil oxygen during waterlogging can be inferred from a low redox value (Malik et al., 2015; Patrick et al., 1996; Wiraguna et al., 2017; Zaman et al., 2018). Oxygen was limited for plant growth - e.g. germination failure and reduction of seedling survival - when redox potential was lower than $300 \mathrm{mV}$ (Husson, 2013; Patrick and Mahapatra, 1968). In this experiment, redox values were recorded by inserting platinum electrodes at a depth of $100 \mathrm{~mm}$ in 12 pots (6 controls; 6 waterlogged and drained treatments) (Patrick et al., 1996).

\section{Experiment 3 - Evaluating the effect of seed priming on waterlogging response of 26 genotypes selected from the diversity panel}

Experiment 3 comprised of 3 factors: duration of waterlogging (2 levels), seed priming (2 treatments) and grass pea genotypes (26) in an RCBD replicated 3 times. The first factor had two levels of duration of waterlogging: 0 and 6 days followed by 8 days of drainage. The second factor was 
seed priming comprising the treatments with or without priming by soaking the seeds in $6 \mathrm{~L}$ of DI water overnight (8-10 hours) at $25^{\circ} \mathrm{C}$ (Harris et al., 2001; Sarker et al., 2004). The third factor was 26 genotypes (Table 1), selected from Experiment 2 to represent groups with different patterns of seedling survival over time - including both waterlogging tolerant and sensitive genotypes while retaining some diversity for origin. The pot system, soil type and sowing were as described for Experiment 2. The experiment was terminated at 14 DAS.

\section{Measurements}

In Experiment 1, plants were identified as flowering when more than $50 \%$ of the plants in a pot had produced a flower and mature when $\sim 90 \%$ of pods formed to grey colour, respectively, (Erskine et al., 1990; Wiraguna et al., 2017). Pod width, pod length, and the number of seeds per pod were recorded according to Campbell (1997) and Polignano et al. (2005). Pods were threshed, and then seeds counted and 100-seed weight (g) was measured as described by Wiraguna et al. (2017).

Seed viability for each genotype was recorded by testing germination of seeds in Petri dishes for 6 days in a temperature-controlled room $\left(25^{\circ} \mathrm{C}\right)$ (Table 1). In Experiments 2 and 3, the numbers of germinated seeds/seedlings were recorded daily with a seed categorised as germinated when a radicle of 5-6 mm was produced (Kranner et al., 2010; Wiraguna et al., 2017). Germination (\%) under waterlogging was calculated as the number of germinated seeds during waterlogging at 6 DAS in waterlogged treatment divided by the number of germinated seeds in drained control multiplied by 100. Percent seedling survival was calculated using Equation 1 for Experiment 2 and Equation 2 for Experiment 3 (below), where CT represents drained control and WL represents waterlogged treatment. Soil redox potential was measured daily as described by Wiraguna et al. (2017).

$$
\begin{aligned}
& \text { Daily seedling survival }(\%)=\left(\frac{\text { Number of surviving seedlings in WL }}{\text { Number of surviving seedlings in CT at harvest }}\right) \times 100, \\
& \text { Seedling survival at harvest }(\%)=\left(\frac{\text { Number of surviving seedlings at harvest }}{\text { Number of viable seeds sown }}\right) \times 100
\end{aligned}
$$

\section{Statistical analyses}

The data were analysed by analysis of variance (ANOVA), canonical analysis and restricted maximum likelihood (REML) with an RCBD to test for the effects of treatments, genotypes and interactions using R-studio version 1.0.136 and GenStat edition $18^{\text {th }}$ (VSN International, UK). Significant differences were tested at $p=0.05$.

Hierarchical clustering analysis was carried out in Experiment 2 by R-studio based on percent seedling survival between 4 and 14 DAS as described by Ward (1963). Canonical analysis was computed by contrasting the variation of morpho-agronomic traits between and within countries of origin (Erskine et al., 1989).

\section{Results}

\section{Experiment 1 - Morpho-agronomic variation by country of origin}

For all morpho-agronomic traits, except the number of seeds per pod, there were significant differences $(p<0.001)$ amongst genotypes and countries of origin (Table 2$)$. Number of seeds per pod was not used further in the analysis. The mean percentage between germination and seedling survival from Bangladesh and Ethiopia was similar, but the mean percentage between germination and seedling survival from Afghanistan and Pakistan was not (Table 2).

Data of seven morpho-agronomic traits were normally distributed (Supplementary Figure S1; Supplementary Table S1). Seedling survival was not significantly correlated with germination (Table 3) and high germination did not always result in high seedling survival (Tables 1 and 2). 
Table 2. Multiple comparisons (Fisher's least significant difference) of 53 grass pea genotypes based on country of origin of seedling survival (\%) when seeds are sown into waterlogged soil and with subsequent drainage, germination (\%) under waterlogged soil, flowering time $(\mathrm{d})$, maturity time $(\mathrm{d}), 100$-seed weight $(\mathrm{g})$, pod width $(\mathrm{cm})$, pod length $(\mathrm{cm})$ and the number of seeds per pod by one-way ANOVA

\begin{tabular}{|c|c|c|c|c|c|c|c|c|}
\hline Country of origin & $\begin{array}{c}\text { Seedling } \\
\text { survival } \\
(\%)\end{array}$ & $\begin{array}{c}\text { Germination } \\
(\%)\end{array}$ & $\begin{array}{l}\text { Flowering } \\
\text { time (d) }\end{array}$ & $\begin{array}{l}\text { Time to } \\
\text { maturity } \\
\text { (d) }\end{array}$ & $\begin{array}{l}100 \text {-seed } \\
\text { weight }(\mathrm{g})\end{array}$ & $\begin{array}{l}\text { Pod } \\
\text { width } \\
(\mathrm{cm})\end{array}$ & $\begin{array}{l}\text { Pod } \\
\text { length } \\
(\mathrm{cm})\end{array}$ & $\begin{array}{c}\text { Number } \\
\text { of } \\
\text { seeds } \\
\text { per pod }\end{array}$ \\
\hline Afghanistan (9) & $4.9^{b c} \pm 2.6$ & $41^{b} \pm 4.6$ & $43^{d} \pm 4.1$ & $108^{\mathrm{ab}} \pm 4.1$ & $12^{b c} \pm 0.9$ & $1.1^{c} \pm 0.1$ & $3.8^{\mathrm{a}} \pm 0.1$ & $3.6 \pm 0.2$ \\
\hline Australia (3) & $3.0^{b c} \pm 3.0$ & $30^{\mathrm{bc}} \pm 7.2$ & $49^{b c} \pm 6.8$ & $108^{\mathrm{abc}} \pm 6.8$ & $14^{\mathrm{abc}} \pm 3.9$ & $1.1^{\mathrm{ab}} \pm 0.1$ & $3.5^{\mathrm{ab}} \pm 0.2$ & $3.0 \pm 0.6$ \\
\hline Bangladesh (3) & $54^{\mathrm{a}} \pm 6.4$ & $59^{a b} \pm 11$ & $46^{\mathrm{bcd}} \pm 2.8$ & $91^{c} \pm 2.8$ & $8.9^{\mathrm{cd}} \pm 1.0$ & $0.9^{b c} \pm 0.0$ & $3.0^{c} \pm 0.1$ & $3.2 \pm 0.3$ \\
\hline Cyprus (11) & $10^{b c} \pm 3.8$ & $14^{c} \pm 2.6$ & $48^{b c} \pm 3.3$ & $111^{\mathrm{a}} \pm 3.3$ & $15^{\mathrm{ab}} \pm 1.1$ & $1.2^{\mathrm{a}} \pm 0.0$ & $3.5^{\mathrm{ab}} \pm 0.1$ & $3.1 \pm 0.1$ \\
\hline Ethiopia (10) & $47^{\mathrm{a}} \pm 6.3$ & $62^{\mathrm{a}} \pm 4.1$ & $44^{c d} \pm 4.7$ & $101^{b c} \pm 4.7$ & $7.6^{d} \pm 0.2$ & $0.9^{c} \pm 0.0$ & $3.1^{c} \pm 0.1$ & $3.2 \pm 0.1$ \\
\hline Greece (8) & $14^{\mathrm{b}} \pm 5.8$ & $18^{\mathrm{C}} \pm 6.3$ & $52^{\mathrm{b}} \pm 3.9$ & $115^{\mathrm{a}} \pm 3.9$ & $18^{\mathrm{a}} \pm 2.7$ & $1.2^{\mathrm{a}} \pm 0.1$ & $3.9^{\mathrm{a}} \pm 0.1$ & $3.2 \pm 0.4$ \\
\hline Pakistan (9) & $1.7^{\mathrm{c}} \pm 0.7$ & $75^{a} \pm 3.9$ & $72^{\mathrm{a}} \pm 1.1$ & $111^{\mathrm{a}} \pm 1.1$ & $8.9^{c d} \pm 0.3$ & $0.9^{c} \pm 0.0$ & $3.5^{b} \pm 0.1$ & $3.8 \pm 0.2$ \\
\hline Mean & 17.4 & 41.9 & 50.9 & 107.8 & 12.2 & 1.1 & 3.5 & 3.3 \\
\hline F probability $(p)$ & $<0.001$ & $<0.001$ & $<0.001$ & $<0.05$ & $<0.001$ & $<0.001$ & $<0.001$ & ns \\
\hline
\end{tabular}

Values within a column followed by different letters indicate a significant difference with the least significant difference (LSD) at $p=0.05$. Differences between countries of origin were significant for all traits, except the number of seeds per pod. Genotype numbers are in parentheses. Data are means followed by the error of three replicates. The traits of flowering time (d), maturity time (d), 100-seed weight $(\mathrm{g})$, pod width $(\mathrm{cm})$, pod length $(\mathrm{cm})$ and the number of seeds per pod were derived from Experiment 1 , where plants were grown in a glasshouse without shading (PAR $=897 \pm 3 \mu \mathrm{mol} \mathrm{m}^{-2} \mathrm{~s}^{-1}$ at midday). Seedling survival (\%) and germination (\%) were derived from Experiment 2, where seeds were sown in a glasshouse under waterlogging for 6 days and drainage for 8 days with $90 \%$ shading (PAR $=59 \pm 4 \mu \mathrm{mol} \mathrm{m} \mathrm{m}^{-2} \mathrm{~s}^{-1}$ at midday). Seedling survival (\%) at the final sampling and germination (\%) under waterlogging were obtained by dividing treatment data by the final number of surviving seedlings of control in Experiment 2 .

Table 3. Pearson correlations ( $r$ ) between morpho-agronomic traits from 53 grass pea genotypes - flowering time (d), maturity time $(\mathrm{d}), 100$-seed weight $(\mathrm{g})$, pod width $(\mathrm{cm})$, pod length $(\mathrm{cm})$, percent germination under waterlogging and percent seedling survival at the final sampling

\begin{tabular}{|c|c|c|c|c|c|c|}
\hline & Time to flowering & Time to maturity & 100 -seed weight & Pod width & Pod length & Germination \\
\hline Maturity time & $-0.39^{\star \star}$ & & & & & \\
\hline 100-seed weight & 0.09 & $-0.33^{\star}$ & & & & \\
\hline Pod width & -0.23 & -0.14 & $-0.81^{\star \star \star}$ & & & \\
\hline Pod length & -0.12 & $-0.36^{\star \star}$ & $-0.52^{\star \star \star}$ & $-0.45^{\star \star \star}$ & & \\
\hline Germination & 0.11 & -0.16 & $-0.54^{\star \star \star}$ & $-0.58^{\star \star \star}$ & $-0.37^{\star \star}$ & \\
\hline Seedling survival & -0.21 & -0.23 & $-0.33^{\star}$ & -0.19 & $-0.35^{\star \star}$ & -0.01 \\
\hline
\end{tabular}

The traits of flowering time, maturity time, seed weight, pod width, pod length and the number of seeds per pod were derived from Experiment 1, where plants were grown in a glasshouse without shading (PAR $=897 \pm 3 \mu \mathrm{mol} \mathrm{m} \mathrm{m}^{-2} \mathrm{~s}^{-1}$ at midday). Seedling survival (\%) and germination (\%) were derived from Experiment 2, where seeds were sown in a glasshouse under waterlogging for 6 days and drainage for 8 days with $90 \%$ shading (PAR $=59 \pm 4 \mu \mathrm{mol} \mathrm{m}^{-2} \mathrm{~s}^{-1}$ at midday). Seedling survival (\%) at final sampling and germination (\%) under waterlogging were obtained by dividing treatment data by the final number of surviving seedlings of control in Experiment 2.

WL, waterlogging.

${ }^{\star} p<0.05 ;{ }^{\star \star} p<0.01 ;{ }^{\star \star \star} p<0.001$.

Genotypes from Afghanistan, for example, had the highest percent germination but most of these germinated seeds did not survive to the final sampling (Table 2). Therefore, only seedling survival was used further in the analysis. Correlations between seedling survival and the other traits demonstrated that seedling survival was significantly correlated with seed weight and pod length. Correlation between seedling survival and pod length was stronger than between seedling survival and seed weight (Table 3).

Canonical analysis reduced the morpho-agronomic data from six variables (seed weight, pod length, pod width, flowering time, time to maturity and seedling survival) to two orthogonal axes (Figure 1). The first two canonical variates accounted for $94.7 \%$ of the total observed variation, with $68.4 \%$ and $26.3 \%$ of variation explained in canonical variates 1 and 2 , respectively. The first canonical variate (CV 1) represented a separation based mainly on seedling survival. The second 


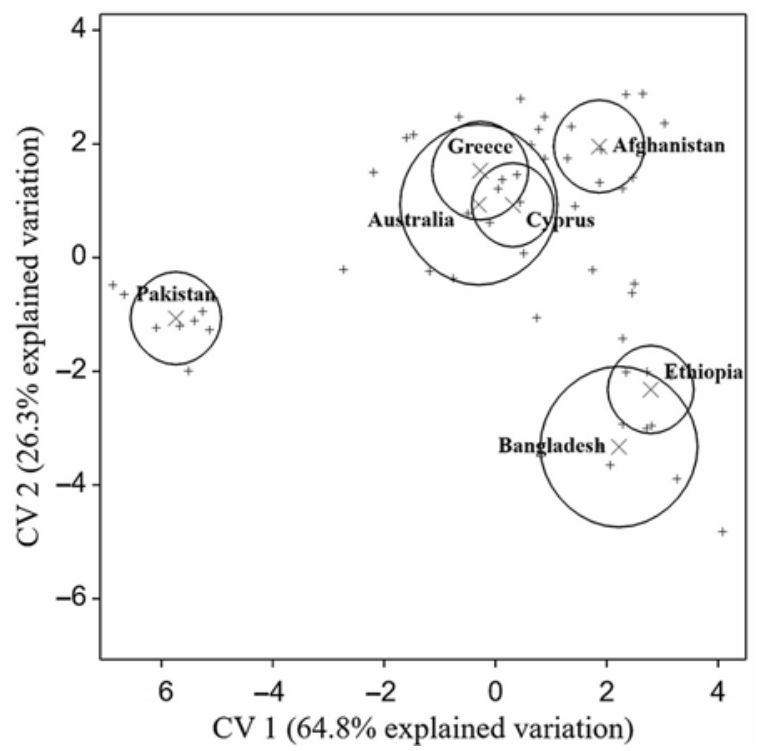

Figure 1. Canonical variate analysis of 53 grass pea genotypes by country of origin using morpho-agronomic traits (Experiment 1 - seed weight, pod length, pod width, flowering time and time to maturity) and percent seedling survival at the final sampling when seed is sown into waterlogged soil and with subsequent drainage (Experiment 2). Cross and plus symbols represent the mean of individual information from the same county of origin and 53 genotypes, respectively. Circles represent confidence limits at $p=0.05$.

canonical variate (CV 2) represented the variation mainly based on seed weight (Supplementary Table S2). The canonical analysis emphasised the similarity of genotypes from Bangladesh and Ethiopia, which had high seedling survival after waterlogging, small seeds (Bangladesh $9 \pm 1.0 \mathrm{~g}$

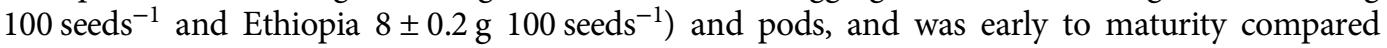
to genotypes from other origins (Table 2). By contrast, genotypes from the Mediterranean region (Greece and Cyprus) were also similar to each other and exhibited poor seedling survival after waterlogging (Greece $14 \pm 5.8 \%$ and Cyprus $10 \pm 3.8 \%$ ), late maturity (Greece $115 \pm 3.9 \mathrm{~d}$ and Cyprus $111 \pm 3.3 \mathrm{~d}$ ), large seeds (Greece $18 \pm 2.7$ and Cyprus $15 \pm 1.1 \mathrm{~g}$ per 100 seeds) and long, wide pods (Figure 1 and Table 2).

\section{Experiment 2 - Screening a diversity panel for waterlogging tolerance at germination and seedling establishment}

Redox measurements showed low soil oxygen during waterlogging, but the oxygen was high following drainage in the controls. In waterlogged pots, the mean redox potential was $226 \pm 13 \mathrm{mV}$ (oxygen is limited at redox $<300 \mathrm{mV}$ - Husson, 2013) during waterlogging, but after draining, the redox potential increased to $321 \pm 15 \mathrm{mV}$ by 8 days at the end of Experiment 2 . In control pots at the start of Experiment 2, the mean soil redox potential was $355 \pm 25 \mathrm{mV}$ and this redox potential remained high at $399 \pm 28 \mathrm{mV}$ at the end of the experiment.

A one-way ANOVA of seedling survival showed significant differences between genotypes in response to waterlogging at final sampling $(p<0.001)$ (Supplementary Table S3). Waterlogging had a severe impact on seedling survival where the average survival overall genotypes was only $17 \%$ seedlings, relative to control at the final sampling after 8 days of drainage (Table 1). Almost one-quarter of genotypes (13 out of 53) failed to have even a single surviving seedling at final sampling. By contrast, six genotypes namely - GP.13 (Ethiopia), GP.16 (Ethiopia), GP.27 
(a)

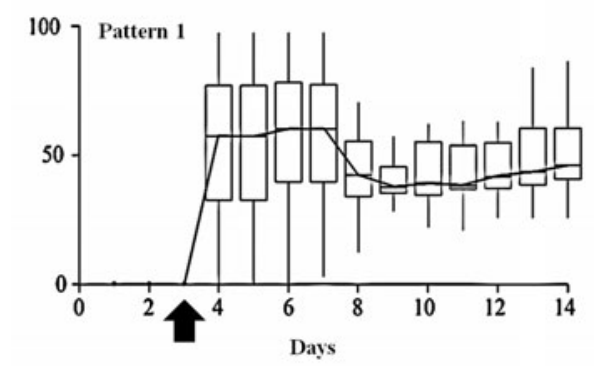

(b)
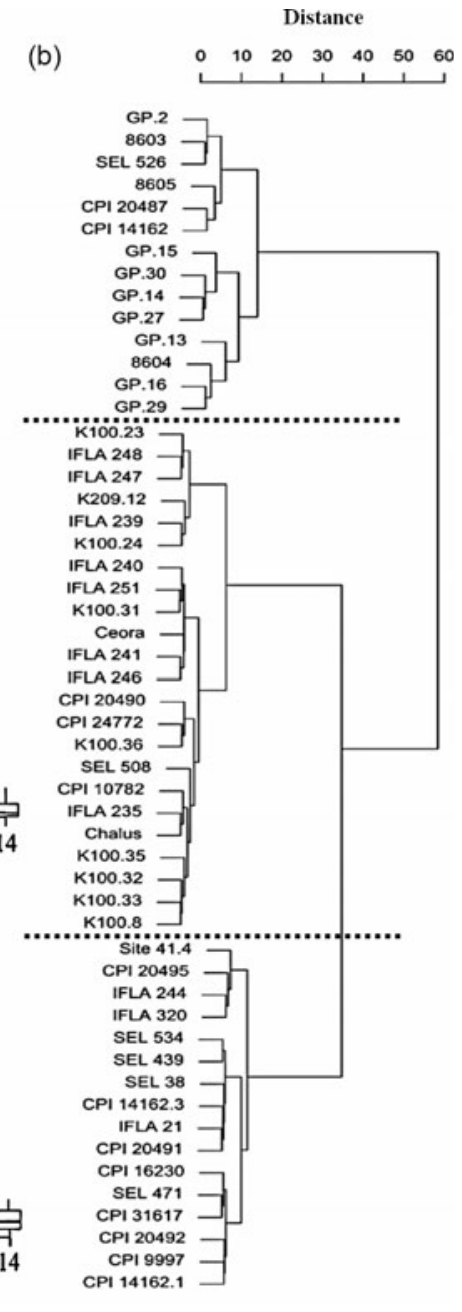

Figure 2. Seedlings (percentage of seedling survival relative to the final number of surviving seedlings of control) for 6 days of waterlogging followed by 8 days of drainage (a) and dendrogram of 53 grass pea genotypes based on similarity for percent seedling survival during waterlogging ( 6 days) and drainage (8 days) (b) (Experiment 2). Pattern 1 represented for seeds that germinated during waterlogging and survive during drainage, Pattern 2 represented for seeds that germinated during waterlogging but cannot survive during drainage and Pattern 3 represented for seeds that did not germinate or had low seedling survival during waterlogging and during draining. The line in each pattern indicated the fitted value of percent seedling survival. Most seeds started to emerge in control at 3 days after sowing (DAS) shown by black arrows. The dotted lines indicated the difference between seedling patterns.

(Ethiopia), GP.29 (Ethiopia), 8604 (Bangladesh) and 8605 (Bangladesh) - showed a high percent seedling survival after waterlogging and drainage - above $45 \%$ (Table 1).

Using the daily surviving seedling data, i.e. daily total number of seedlings during 6 days of waterlogging followed by 8 days of drainage (Supplementary Table S4), a hierarchical cluster analysis was conducted to produce a dendrogram comparing the 53 genotypes (Figure $2 \mathrm{a}$ and b). Three major patterns were found with Pattern 1 clustered as waterlogging-tolerant genotypes, and Patterns 2 and 3 were classified as waterlogging-sensitive genotypes (Table 1 and Figure $2 \mathrm{a}$ and $\mathrm{b}$ ). Pattern 1 is composed of genotypes that germinated under waterlogging and continued to survive during drainage. Pattern 2 comprised of genotypes that germinated under waterlogging but did not survive during drainage. Pattern 3 was of genotypes that failed to 
Table 4. Analysis of restricted maximum likelihood (REML) of seedling survival (\%) for 26 grass pea genotypes when sown into waterlogged soil and subsequently drained

\begin{tabular}{lcrrrr}
\hline Fixed term & Wald statistic & ndf & F statistic & ddf & F probability $(p)$ \\
\hline Genotype & 87.42 & 25 & 3.50 & 192 & $<0.001$ \\
Waterlogging & 597.68 & 1 & 597.68 & 192 & $<0.001$ \\
Seed priming & 32.49 & 1 & 32.49 & 192 & $<0.001$ \\
Genotype $\times$ Waterlogging & 139.07 & 25 & 5.56 & 192 & $<0.001$ \\
Genotype $\times$ Seed priming & 35.44 & 25 & 1.42 & 192 & 0.099 \\
Seed priming $\times$ Waterlogging & 0.24 & 1 & 0.24 & 192 & 0.628 \\
Genotype $\times$ Waterlogging $\times$ Seed priming & 17.69 & 25 & 0.71 & 192 & 0.846 \\
\hline
\end{tabular}

A total of 26 genotypes from 7 countries of origin with 3 seedling survival patterns: Pattern 1 (Germination under waterlogging and survival after draining), Pattern 2 (Germination under waterlogging but no survival after draining) and Pattern 3 (Sensitive to waterlogging) were waterlogged for 6 days and drainage for 8 days in a glasshouse under $90 \%$ shade (PAR $=59 \pm 4 \mu \mathrm{mol} \mathrm{m}^{-2} \mathrm{~s}^{-1}$ at midday). Seed priming was carried out by soaking seeds in DI water overnight $(8-10 \mathrm{~h})$. Seedling survival was derived after dividing treatment data by the number of seeds sown (Experiment 3).

ndf, numerator degrees of freedom; ddf, denominator degrees of freedom.

germinate or had low seedling survival during waterlogging and drainage (Figure 2a). Pattern 1 consisted of 14 genotypes with 1 genotype from Cyprus (CPI 20487), 1 genotype from Greece (CPI 14162), 3 genotypes from Bangladesh and 9 genotypes from Ethiopia (Table 1). All genotypes from Ethiopia, except genotype SEL 508, and from Bangladesh were clustered in Pattern 1 (Table 1 and Figure 2b). Genotypes from Cyprus and Greece showed the broadest diversity since genotypes from these two countries were classified in all three clusters (Table 1).

\section{Experiment 3 - Evaluating the effect of seed priming on seedling survival after waterlogging}

Analysis of REML demonstrated that the interaction between seed priming and waterlogging treatment was not significant (Table 4), whereas the main effects for seed priming, genotype and waterlogging and the interaction genotype $\times$ waterlogging were all significant. Seed priming reduced seedling survival from 87 to $77 \%$ in control and from 19 to $7 \%$ in waterlogging treatment (Supplementary Figure S2). The mean seedling survival of primed seeds was $42 \%$, whereas for nonprimed seeds, it was $53 \%$. Seed priming had no significant interaction with genotype and waterlogging (Table 4). Interaction between genotype and waterlogging treatment was significant $(p<0.001)$ confirming the results of Experiment 2 that genotypes differed in waterlogging tolerance (Table 4 ).

\section{Discussion}

Variation in waterlogging tolerance during the seedling stage has been reported within legume species including lupin (Lupinus albus L.) (Davies et al., 2000), faba bean (Solaiman et al., 2007), soybean (Henshaw et al., 2007), lotus (Lotus spp.) (Real et al., 2008) and chickpea (Palta et al., 2010). However, only a few studies have demonstrated variation in waterlogging tolerance at germination in legumes (Malik et al., 2015; Wiraguna et al., 2017; Zaman et al., 2019b). A species comparison using between one and three genotypes, indicated that grass pea is more tolerant to waterlogging at germination than lentil and field pea (Malik et al., 2015). However, there was no information on the variation within grass pea in waterlogging tolerance and whether any such variation might be related to adaptation and selection of grass pea to local environments. In this study, we found that waterlogging tolerance at germination and seedling survival upon soil drainage differed amongst grass pea genotypes; and that genotypes from Bangladesh and Ethiopia were more tolerant than those from other origins.

Genotypes from the Mediterranean region (Greece and Cyprus) were late to maturity and had larger seeds than genotypes from Bangladesh (Table 2). While this study had a relatively low number of genotypes from Bangladesh (3), an earlier study with more than 49 genotypes per country (Rajendran et al., 2018) showed a similar result for morpho-agronomic traits of maturity and seed 
weight to this study, where genotypes from Bangladesh mature earlier and have smaller seeds than genotypes from the Mediterranean region. Therefore, despite the low sample size from Bangladesh in this study, morpho-agronomic information of genotypes from Bangladesh can be used to represent this country of origin.

Environmental stress can drive adaptation to local conditions through selection and evolution (Erskine et al., 1989; Hoffmann and Hercus, 2000). Lentil and field pea, for example, originated from the Near East, e.g. northern Syria, with relatively dry and cold conditions during sowing in the month of December (Erskine and El Ashkar, 1993; Gepts, 2004; Silim et al., 1991). In contrast, lentil that was introduced to Bangladesh and field pea that was introduced to Ethiopia have become adapted to waterlogging at germination and to warm conditions through selection because the seeds are sown into waterlogged soil during relay cropping before rice harvest with a mean minimum temperature of $\sim 20^{\circ} \mathrm{C}$ in the month of November for lentil, and during high rainfall in the month of July for field pea (Malik et al., 2016; Telaye, 1979; Tsidu, 2012; Wiraguna et al., 2017; Zaman et al., 2019b). Grass pea is suggested to have originated from the same region as lentil and field pea (the Near East) (Campbell, 1997; Kislev, 1989; Larbi et al., 2010). In our experiment, we found significant variation between genotypes from different countries of origin in tolerance to waterlogging, and genotypes from Bangladesh and Ethiopia are more tolerant to waterlogging than those from other origins (Table 2). Genotypes from Bangladesh and Ethiopia were probably selected for waterlogging tolerance at germination by farmers who sow grass pea seeds into the soil with a high soil moisture content (Campbell et al., 1994; Minta et al., 2014; Tadesse and Bekele, 2001). In Bangladesh, grass pea seeds are sown into waterlogged soil under the relay cropping (Campbell et al., 1994) in similar conditions to that shown for lentil (Malik et al., 2016). In Ethiopia, grass pea seeds are sown in a higher rainfall $(\sim 160 \mathrm{~mm})$ and warmer temperature $\left(\sim 19^{\circ} \mathrm{C}\right)$ (Minta et al., 2014) than at its origin similar to that described for field pea (Telaye, 1979; Tsidu, 2012).

Amongst correlations, the association between germination under waterlogging and seedling survival after waterlogging for 6 days followed by drainage for 8 days in grass pea was non-significant (Table 3 and Figure S1). Genotypes - mainly from Afghanistan, Australia and Pakistan - germinated under waterlogging but subsequently died during drainage to final sampling. However, genotypes mainly from Bangladesh and Ethiopia - germinated under waterlogging and survived during the drainage period to final sampling (Table 1 and Figure 2). These different surviving seedling patterns amongst grass pea genotypes illustrate that seedling survival after waterlogging is an important trait in screening for waterlogging tolerance at germination.

A negative correlation between seedling survival after waterlogging and morpho-agronomic traits, e.g. seed weight, was identified (Sayama et al., 2009; Zaman et al., 2018). Greater waterlogging tolerance in small seeds over large seeds may result from small seeds being exposed to higher oxygen partial pressure than large seeds since soil oxygen can decrease substantially within a few millimetres of soil depth (e.g. oxygen profiles in the soil surface of rice; Frenzel et al., 1992). Moreover, the distance between an embryo and a seed coat is closer in small seeds than in large seeds (Borisjuk and Rolletschek, 2009; Rolletschek et al., 2009), so the diffusion path-length is shorter for oxygen to reach the embryo. In this study, we found a similar response, where small grass pea seeds had higher germination and/or seedling survival (Table 2) than large seeds with significant correlations between seed weight and germination $(r=-0.54)$ and between seed weight and seedling survival $(r=-0.33)$ (Table 3$)$. Significant negative correlations between germination and pod length $(r=-0.37)$ and between seedling survival and pod length $(r=-0.35)$ were identified (Table 3). Waterlogging-tolerant genotypes from Bangladesh and Ethiopia have significantly shorter pods than those from other tested origins, and the mean of pod length of genotypes from Bangladesh is $3.0 \mathrm{~cm}$ and from Ethiopia is $3.1 \mathrm{~cm}$ while the mean of pod length of genotypes from other tested origins is more than $3.5 \mathrm{~cm}$ (Table 2). However, there is no clear mechanistic relationship between pod length and waterlogging tolerance at germination amongst countries of origins, apart from the association of these two traits with seed weight (Percy et al., 1999; Sayama et al., 2009). 
In addition, seed priming can increase seedling emergence in relay cropping systems (Ali et al., 2009; Bhowmick et al., 2014). However, seed priming significantly reduced seedling survival by an average of $10 \%$ in this study. Differing results between relay cropping in a paddy rice field by Bhowmick et al. (2014) and this study were, presumably, due to duration and temperature of seed priming. Grass pea seeds that were previously primed for 6 hours at a minimum of $11^{\circ} \mathrm{C}$ night temperature and then sown in relay cropping system (Bhowmick et al., 2014) increased seedling establishment and grain yield. However, when grass pea seeds were primed for 8-10 hours at a temperature of $25^{\circ} \mathrm{C}$, seedling survival was reduced to $42 \%$. The longer duration and warmer temperature of seed priming in this study than in the previous study by Bhowmick et al. (2014) may cause rapid water imbibition (Kader and Jutzi, 2002; Wuebker et al., 2001) and a solute leakage (Zaman et al., 2019b). Therefore, primed seeds showed a lower percent seedling survival than non-primed seeds in this study.

Genotypes of grass pea from Bangladesh and Ethiopia have similar morpho-agronomic traits and are more adapted to waterlogging at germination than genotypes from other tested origins. Even though grass pea originates from the Mediterranean with relatively dry conditions (albeit cool and moist at the typical time of germination), local environment and agricultural practice such as relay cropping have forced grass pea to adapt to wet and warm conditions. Recently unseasonal rains after sowing in November from climate change in Bangladesh have destroyed much of the crop discouraging its cultivation. The identification of waterlogging tolerance gives encouragement to the prospect of improved adaptation. The adaptation of grass pea to wet and warm conditions at germination is encouraging for possible specific selection in other legume crops for improved tolerance to waterlogging at germination.

\section{Conclusion}

There was a significant variation amongst grass pea genotypes to waterlogging stress at germination and seedling survival upon soil drainage. Genotypes from Bangladesh and Ethiopia were more adapted to soil waterlogging than those from other origins. The tolerant genotypes were able to germinate under waterlogging and continue growing (during drainage) until the end of the experiment. Genotypes from Bangladesh and Ethiopia had a similarity of morpho-agronomic traits of early maturity, small pods and seeds. Seed priming overnight $(8-10$ hours $)$ at $25^{\circ} \mathrm{C}$ did not increase the tolerance of grass pea seeds to being sown into waterlogged soil.

Supplementary material. To view supplementary material for this article, please visit https://doi.org/10.1017/ S0014479720000356.

Acknowledgments. E.W. thanks the Indonesia Endowment Fund for Education, the Ministry of Finance of the Republic of Indonesia (LPDP). The authors thank the Australian Centre for Agricultural Research (ACIAR project CIM-2014-076). The authors are thankful to Katia Stefanova for advice on data analysis. The Australian Grains Genebank is gratefully acknowledged for providing the grass pea germplasm.

Conflict of Interest. The authors declare there is no conflict of interest.

\section{References}

Ali M., Singh K., Pramanik S. and Ali M.O. (2009). Cropping systems and production agronomy. In Erskine W, Muehlbauer FJ, Sarker A and Sharma B (eds), The Lentil: Botany, Production and Uses. Oxfordshire, UK: CAB International, pp. 213-228.

Benková M. and Žáková M. (2001). Evaluation of selected traits in grasspea (Lathyrus sativus L.) genetic resources. Lathyrus Lathyrism Newsletter 2, 27-30.

Bhowmick M. K. (2010). Effect of planting time and seed priming on growth and yield of lentil under rice-utera system. Journal of Food Legumes, 23(2), 152-153.

Bhowmick M.K., Dhara M.C., Duray B., Biswas P.K. and Bhattacharyya P. (2014). Improvement of lathyrus productivity through seed priming and foliar nutrition under rice-utera system. Journal of Crop and Weed 10, 277-280. 
Borisjuk L. and Rolletschek H. (2009). The oxygen status of the developing seed. New Phytologist 182, 17-30. doi: 10.1111/j. 1469-8137.2008.02752.x

Campbell C.G., Mehra R.B., Agrawal S.K., Chen Y.Z., Abd El Moneim A.M., Khawaja H.I.T., Yadav C.R., Tay J.U. and Araya W.A. (1994). Current status and future strategy in breeding grasspea (Lathyrus sativus). Euphytica 73,167-175.

Campbell C.G. (1997). Grass pea, Lathyrus sativus L, Promoting the conservation and use of underutilized and neglected crops. 18. Institute of Plant Genetics and Crop Plant Research, Gatersleben/International Plant Genetic Resources Institute, Rome, Italy, pp. 8-53.

Choudhary V.K., Chander S., Chethan C.R. and Kumar B. (2019). Effect of seed priming on abiotic stress tolerance in plants. In Hasanuzzaman M, Fujita M, Oku H and Islam MT (eds), Plant Tolerance to Environmental Stress: Role of Phytoprotectants. Florida, USA: CRC Press, pp. 29-40.

Davies C.L., Turner D.W. and Dracup M. (2000). Yellow lupin (Lupinus luteus) tolerates waterlogging better than narrowleafed lupin (L. angustifolius) I. Shoot and root growth in a controlled environment. Australia Journal of Agricultural Research 51, 701-709.

Erskine W. and El Ashkar F. (1993). Rainfall and temperature effects on lentil (Lens culinaris) seed yield in Mediterranean environments. Journal of Agricultural Science 121, 347-354.

Erskine W., Adham Y. and Holly L. (1989) Geographic distribution of variation in quantitative traits in a world lentil collection. Euphytica 43, 97-103. doi: 10.1007/BF00037901

Erskine W., Muehlbauer F.J. and Short R.W. (1990). Stages of development in lentil. Experimental Agriculture 26,297-302.

Frenzel P., Rothfuss F. and Conrad R. (1992). Oxygen profiles and methane turnover in a flooded rice microcosm. Biology and Fertility of Soils 14, 84-89.

Gepts P. (2004). Crop domestication as a long-term selection experiment. In Janick J (ed.), Plant Breeding Reviews. New Jersey, USA: John Wiley \& Sons, Inc., pp. 1-37.

Gupta S. and Bhowmick M.K. (2005). Scope of growing lathyrus and lentil in relay cropping systems after rice in West Bengal, India. Lathyrus Lathyrism Newsletter 4, 28-33.

Harris D., Joshi A., Khan P.A., Gothkar P. and Sodhi P.S. (1999). On-farm seed priming in semi-arid agriculture: development and evaluation in maize, rice and chickpea in India using participatory methods. Experimental Agriculture 35, 15-29.

Harris D., Pathan A.K, Gothkar P., Joshi A., Chivasa W. and Nyamudeza P. (2001). On-farm seed priming: Using participatory methods to revive and refine a key technology. Agricultural Systems 69, 151-164.

Henshaw T.L., Gilbert R.A., Scholberg J.M.S. and Sinclair T.R. (2007) Soya bean (Glycine max L. Merr.) genotype response to early-season flooding: II. Aboveground growth and biomass. Journal of Agronomy Crop Science 193, 189-197. doi: 10. 1111/j.1439-037X.2007.00258.x

Hoffmann A.A. and Hercus M.J. (2000) Environmental stress as an evolutionary force. Bioscience 50(3), 217-226.

Hsu S.K. and Tung C.W. (2017) RNA-Seq analysis of diverse rice genotKaderypes to identify the genes controlling coleoptile growth during submerged germination. Frontier in Plant Science 8, 762. doi: 10.3389/fpls.2017.00762

Husson O. (2013) Redox potential (Eh) and $\mathrm{pH}$ as drivers of soil/plant/microorganism systems: a transdisciplinary overview pointing to integrative opportunities for agronomy. Plant and Soil 362, 389-417. doi: 10.1007/s11104-012-1429-7

Ismail A.M., Ella E.S., Vergara G.V. and Mackill D.J. (2009) Mechanisms associated with tolerance to flooding during germination and early seedling growth in rice (Oryza sativa). Annals of Botany 103, 197-209. doi: 10.1093/aob/mcn211

Johnson J., Cobb B.G. and Drew M.C. (1989) Hypoxic induction of anoxia tolerance in root tips of Zea mays. Plant Physiology 91(3), 837-841.

Kader M.A. and Jutzi S.C. (2002). Temperature, osmotic pressure and seed treatments influence imbibition rates in sorghum seeds. Journal of Agronomy and Crop Science 188, 286-290.

Kislev M.E. (1989). Origins of the cultivation of Lathyrus sativus and L. cicera (fabaceae). Economic Botany 43, $262-270$.

Kranner I., Roach T., Beckett R.P., Whitaker C. and Minibayeva F.V. (2010) Extracellular production of reactive oxygen species during seed germination and early seedling growth in Pisum sativum. Journal of Plant Physiology 167, 805-811. doi: 10.1016/j.jplph.2010.01.019

Larbi A., Hassan S., Kattash G., Abd El-Moneim A., Jammal B., Nabil H. and Nakkoul H. (2010) Annual feed legume yield and quality in dryland environments in north-west Syria: 1. Herbage yield and quality. Animal Feed Science and Technology 160, 81-89. doi: 10.1016/j.anifeedsci.2010.07.003

Malik A.I., Ailewe T.I. and Erskine W. (2015) Tolerance of three grain legume species to transient waterlogging. AoB Plants 7, 1-11. doi: 10.1093/aobpla/plv040

Malik A.I., Ali M.O., Zaman M.S., Flower K., Rahman M.M. and Erskine W. (2016) Relay sowing of lentil (Lens culinaris subsp. culinaris) to intensify rice-based cropping. Journal of Agricultural Science 154, 850-857. doi: 10.1017/S0021859614001324

Minta M., Assefa G. and Feyissa F. (2014) Potential of feed-food double-cropping in central highlands of Ethiopia. Archives Agronomy and Soil Science 60(9), 1249-1260. doi: 10.1080/03650340.2013.878456

Orchard P.W. and So H.B. (1985). The response of sorghum and sunflower to short-term waterlogging. Plant and Soil 88,407-419.

Palta J.A., Ganjeali A., Turner N.C. and Siddique K.M.H. (2010) Effects of transient subsurface waterlogging on root growth, plant biomass and yield of chickpea. Agricultural Water Management 97, 1469-1476. doi: 10.1016/j.agwat.2010.05.001 
Patrick W.H., Gambrell R.P. and Faulkner S.P. (1996) Redox measurements of soils. In: Methods of Soil Analysis. Part 3. Chemical Methods, SSSA Book Series No. 5. SSSA/ASA, Madison, WI, USA, pp. 1255-1273.

Patrick W.M.H. and Mahapatra I.C. (1968) Transformation and availability to rice of nitrogen and phosphorus in waterlogged soils. Advances in Agronomy 20, 323-359. doi: 10.1016/S0065-2113(08)60860-3

Percy J.D., Philip R. and Vodkin L.O. (1999). A defective seed coat pattern (Net) is correlated with the post-transcriptional abundance of soluble proline-rich cell wall proteins. Plant Molecular Biology 40, 603-613.

Polignano G., Uggenti P., Alba V., Bisignano V. and Gatta C.D. (2005) Morpho-agronomic diversity in grass pea (Lathyrus sativus L.). Plant Genetic Resources 3(1), 29-34. doi: 10.1079/PGR200455

Rajendran K., Sarker A., Singh M., El-Moneim A.M.A. and Nakkoul H. (2018) Characterization of grass pea (Lathyrus sativus L.) germplasm collections for beneficial agronomic traits. Indian Journal of Genetics 78(3), 357-363. doi: 10. 31742/IJGPB.78.3.8

Real D., Warden J., Sandral G.A. and Colmer T.D. (2008). Waterlogging tolerance and recovery of 10 Lotus species. Australian Journal of Experimental Agriculture 48, 480-487.

Rolletschek H., Stangelmayer A. and Borisjuk L. (2009). Methodology and significance of microsensor-based oxygen mapping in plant seeds-an overview. Sensors 9, 3218-3227. doi: 10.3390/s90503218

Sarkar R.K. (2012) Seed priming improves agronomic trait performance under flooding and non-flooding conditions in rice with QTL SUB1. Rice Science 19(4), 286-294.

Sarker A., Erskine W., Bakr M.A., Rahman M.M., Afzal A.M. and Saxena M.C. (2004) Lentil improvement in Bangladesh. A success story of fruitful partnership between the Bangladesh Agricultural Research Institute and the International Center for Agricultural Research in the Dry Areas. APAARI Publication 1, pp. 1-38.

Sayama T., Nakazaki T., Ishikawa G., Yagasaki K., Yamada N., Hirota N., Hirata K., Yoshikawa T., Saito H., Teraishi M., Okumoto Y., Tsukiyama T. and Tanisaka T. (2009) QTL analysis of seed-flooding tolerance in soybean (Glycine max [L.] Merr.). Plant Science 176(4), 514-521. doi: 10.1016/j.plantsci.2009.01.007

Silim S.N., Saxena M.C. and Erskine W. (1991). Effect of sowing date on the growth and yield of lentil in a rainfed Mediterranean environment. Experimental Agriculture 27, 145-153.

Solaiman Z., Colmer T.D., Loss S.P., Thomson B.D. and Siddique K.M.H. (2007). Growth responses of cool-season grain legumes to transient waterlogging. Crop and Pasture Science 58, 406-412.

Tadesse W. and Bekele E. (2001). Isozymes variability of grasspea (Lathyrus sativus L.) in Ethiopia. Lathyrus Lathyrism. Newsletter 2, 43-46.

Telaye A. (1979). Broad beans (Vicia faba) and dry peas (Pisum sativum) in Ethiopia. In Proceedings of the Food Legume Improvement and Development Workshop held at the University of Aleppo. C. Geoffrey, Hawtin, and G. J. Chancellor (eds), Aleppo: International Center for Agricultural Research in the Dry Areas and the International Development Research Centre), pp. 80-84.

Tsidu G.M. (2012). High-resolution monthly rainfall database for Ethiopia: homogenization, reconstruction, and gridding. Journal of Climate 25, 8422-8443. doi: 10.1175/JCLI-D-12-00027.1

Ward J.H. (1963) Hierarchical grouping to optimize an objective function. Journal of American Statistic Association 58(301), 236-244. doi: 10.1080/01621459.1963.10500845

Wiraguna E., Malik A.I. and Erskine W. (2017) Waterlogging tolerance in lentil (Lens culinaris Medik. subsp. culinaris) germplasm associated with geographic origin. Genetic Resources and Crop Evolution 64, 579-586. doi: 10.1007/s10722016-0385-0

Wuebker E.F., Mullen R.E. and Koehler K. (2001). Flooding and temperature effects on soybean germination. Crop Science 41(6), 1857-1861.

Yan Z.Y., Spencer P.S., Li Z.X., Liang Y.M., Wang Y.F., Wang C.Y. and Li F.M. (2006) Lathyrus sativus (grass pea) and its neurotoxin ODAP. Phytochemistry 67, 107-121. doi: 10.1016/j.phytochem.2005.10.022

Yigzaw Y., Gorton L., Akalu G. and Solomon T. (2001). Fermentation of teff (Eragrostis tef), grass-pea (Lathyrus sativus), and their mixtures: Aspects of nutrition and food safety. Lathyrus Lathyrism Newsletter 2, 8-10.

Zaman M.S.U., Malik A.I., Erskine W. and Kaur P. (2019a) Changes in gene expression during germination reveal pea genotypes with either 'quiescence' or 'escape' mechanisms of waterlogging tolerance. Plant, Cell \& Environment 42(1), 245-258. doi: 10.1111/pce.13338

Zaman M.S.U., Malik A.I., Kaur P. and Erskine W. (2018) Waterlogging tolerance of pea at germination. Journal of Agronomy and Crop Science 204, 155-164. doi: 10.1111/jac.12230

Zaman M.S.U., Malik A.I., Kaur P., Ribalta F.M. and Erskine W. (2019b) Waterlogging tolerance at germination in field pea: variability, genetic control, and indirect selection. Frontiers in Plant Science 10, 1-11. doi: 10.3389/fpls.2019.00953

Cite this article: Wiraguna E, Malik AI, Colmer TD, and Erskine W (2020). Waterlogging tolerance of grass pea (Lathyrus sativus L.) at germination related to country of origin. Experimental Agriculture 56, 837-850. https://doi.org/10.1017/ S0014479720000356 